Meta

Journal des traducteurs

Translators' Journal

\title{
Reader Reaction and Workplace Habits in the English Translation of French Proper Names in Canada
}

\section{Brian Mossop}

Volume 52, numéro 2, juin 2007

URI : https://id.erudit.org/iderudit/016066ar

DOI : https://doi.org/10.7202/016066ar

Aller au sommaire du numéro

Éditeur(s)

Les Presses de l'Université de Montréal

ISSN

0026-0452 (imprimé)

1492-1421 (numérique)

Découvrir la revue

Citer cet article

Mossop, B. (2007). Reader Reaction and Workplace Habits in the English Translation of French Proper Names in Canada. Meta, 52(2), 202-214. https://doi.org/10.7202/016066ar
Résumé de l'article

Cet article étudie les facteurs qui peuvent entrer en jeu dans la traduction anglaise des noms de lieux et des noms institutionnels français au Canada : réactions anticipées des lecteurs ; règles énoncées par les clients, employeurs et guides de rédaction; méthodes de travail des traducteurs (traductions coupées-collées ; temps consacré au contrôle de la qualité). Les traductions possibles de cinq noms propres sont commentées : Québec, Radio-Canada, Acadie, Commission québécoise des libérations conditionnelles, Canada/canadien. 


\title{
Reader Reaction and Workplace Habits in the English Translation of French Proper Names in Canada
}

\author{
BRIAN MOSSOP \\ York University, Toronto, Ontario \\ brmossop@yorku.ca
}

\begin{abstract}
RÉSUMÉ
Cet article étudie les facteurs qui peuvent entrer en jeu dans la traduction anglaise des noms de lieux et des noms institutionnels français au Canada: réactions anticipées des lecteurs; règles énoncées par les clients, employeurs et guides de rédaction; méthodes de travail des traducteurs (traductions coupées-collées; temps consacré au contrôle de la qualité). Les traductions possibles de cinq noms propres sont commentées: Québec, Radio-Canada, Acadie, Commission québécoise des libérations conditionnelles, Canada/ canadien.
\end{abstract}

\section{ABSTRACT}

This article looks at factors that might be involved in the translation of French place names and institution names into English in Canada: the anticipated reactions of readers; rules enunciated by clients, employers and style guides; the effects of workplace procedures (reduced quality control time; use of cut-and-paste translation). The possible translations of five proper names are discussed: Québec, Radio-Canada, Acadie, Commission québécoise des libérations conditionnelles, Canada/canadien.

\section{MOTS-CLÉS/KEYWORDS}

French, institution names, place names, proper names, workplace habits

There is a small town north of Montreal whose French name is Shawinigan-Sud. In an English translation of a French text referring to the town, what would it be called? Here are five possibilities: Shawinigan-Sud, Shawinigan Sud, Shawinigan-South, Shawinigan South and South Shawinigan. An Internet search reveals that all five have been used in (original or translated) English texts. The question arises: why in a particular translation does one of these possibilities appear rather than another? In this article I explore some factors that might be involved in the translation of French place names and institution names.

I should immediately mention that I shall be concerned hardly at all with how proper names ought to be translated; prescriptions found in style guides, a few of which I will mention in passing, are simply one of many factors that may influence the translation of a proper name. I shall also not be much concerned with how proper names are in fact translated, though I will report a few results from database and Internet searches and give one or two examples from real translations. What I shall principally be concerned with here is how proper names can be translated, and why one choice rather than another might be made.

In the first part of the article, I will look at factors that might be considered more or less consciously ${ }^{1}$ by the translator, specifically factors related to the translator's 
prediction of how the intended reader will react to a particular translation. For this purpose I will draw on personal experience rather than interviews with other translators. In the latter part of the article, I will look at how various workplace procedures may determine the final translation, possibly overriding considerations related to reader reaction.

\section{Reader reaction factors in the translation of proper names}

Reader reaction to translation can be considered from two points of view: from the point of view of reception, there is the actual reaction of the reader; from the point of view of production, there is the reaction imagined in the mind of the translator. It is the imagined reaction which will be of concern here. The reader I will be thinking of is a unilingual Anglophone living in the city of Vancouver who visits a Web site that contains translated French. I will not be considering the possibly different reactions of readers who have less knowledge of Canada (Americans or Australians for example) or of Anglo-Quebeckers, who will have much more familiarity with Quebec and with French than a Vancouverite. ${ }^{2}$

Here are three kinds of reader reaction that might be taken into consideration by the translator:

- readability: does the wording of the translation make for easy or not-so-easy reading?

- misunderstanding: how likely is it that the reader will attribute a meaning that differs from the French, or perhaps not understand the translation at all?

- cultural awareness: will the translation evoke in the reader a sense that the text emanates from another culture? ${ }^{3}$

\subsection{Québec}

Let's see how these three factors might apply in the translation of the name of the capital city of Quebec. The following table shows six possible translations and rates them in terms of the three factors. I present the translations in a short sentence, which means that I will not be considering the ways in which the rest of the text may influence the reader's reaction; this should not materially affect what I say about the candidate translations.

The meeting will be held in

\begin{tabular}{|l|l|l|l|}
\hline & otherness evoked? & hard to read? & misunderstanding likely? \\
\hline 1. Quebec City & no & no & no \\
\hline 2. Québec City & yes & no & no \\
\hline 3. Québec & yes & no & yes \\
\hline 4. the city of Québec & yes & possibly & no \\
\hline 5. the Quebec capital & no & possibly & information added \\
\hline 6. the province's capital & no & possibly & information added \\
\hline
\end{tabular}

Translation 1 is the city's traditional name in English, and still by far the most common way English-speaking Canadians refer to it, both in speech and in writing. Translation 1 is easy to read and will not give rise to any misunderstanding. However it does not evoke cultural otherness, unlike Translation 2, which does evoke otherness 
through use of the acute accent on the 'é.' Accents are very visible markers of otherness in an English text because they are not part of the English orthographic system. Translation 2 would appear to be ideal if one wants to evoke otherness while retaining readability and avoiding misunderstanding, but interestingly, this translation is specifically disapproved by the Editors' Association of Canada on the ground of its hybrid nature: "Québec City makes no sense in either language" (2000: 77). The English versions of Government of Quebec Web sites (...gouv.qc.ca) regularly use Québec City.

Translation 3 again evokes otherness, and it is not hard to read. However it is very likely to give rise to misunderstanding. Place names very commonly occur after such prepositions as 'to' or (as in the present example) 'in,' and in these cases it may not be clear whether the reference is to the city or to the province of Quebec.

A query in TransSearch (www.tsrali.com), a bilingual database that matches the English and French versions of Canada's parliamentary proceedings (Hansard) for the years 1986-2003, yielded 23 hits for the query "go+..to Quebec City"/aller+...à Québec" (i.e., all those passages where a form of the verb 'go' followed within 25 words by the expression 'to Quebec City' corresponded to a form of the verb 'aller' followed within 25 words by the expression 'à Québec'). There were 0 hits when the English query phrase was set to "go+...to Québec" or "go+...to Québec City." While the database does not distinguish original English from translated English, it is clear that the English version of Hansard does not use the accent mark and also avoids the use of 'Québec' alone for the name of this city.

Interestingly, the usage in Hansard is contrary to the Canadian Government's style guide, The Canadian Style, which says that "Montréal and Québec (the city) retain their accents in English" (1997: 264). The guide takes as its authority the rules of the Geographical Names Board of Canada that were in effect at the time it was published (http: //geonames.nrcan.gc.ca/info/princip1990_e.php). However the Board's members, many of them geographers, were probably thinking not of texts but of maps, where it would be obvious that 'Québec' is a city name, not a province name.

No government-wide official rules have ever been enunciated by a federal authority concerning the translation of French place names into English in running text. However, some government institutions do from time to time provide translators with rules, and these do not necessarily conform with The Canadian Style. For example, the instructions from the Immigration and Refugee Board state that 'Montreal,' 'Quebec' (the province) and 'Quebec City' are to be written without accents. Also, an Alta Vista search of Government of Canada Web sites (...gc.ca) showed that 'Québec City' is used, but not nearly as often as the unaccented form: there were 1,124 hits for the accented form, as compared to 5,254 hits for 'Quebec City.'

The Canadian Style specifies (1997: 269) that the name of the province is 'Quebec' (with no accent). But the above examples of translation instructions and actual texts suggest that the Government's translators and other writers realize that The Canadian Style's contrast ${ }^{5}$ between the city name (with accent) and the province name (without accent) completely ignores the fact that presence versus absence of an accent mark is not a feature that is used to distinguish two words in the English orthographic system. In sentences such as the one under consideration in the chart that begins this section, where the city's name follows a preposition, our unilingual Anglophone in Vancouver 
will not decide whether the city or the province is intended by looking to see whether there is an accent present or not.

Turning now to Translation 4, 'the city of Québec', which happens to be one of the two translations recommended by the City of Montréal Style Guide: "in Québec or in the city of Québec (NOT Quebec City or Québec City)” (2001: 9). This translation evokes otherness (through the accent) and avoids the problem of misunderstanding after prepositions (through the words 'the city of'). However there may be a problem of readability in that this wording may not fit into the structure of certain sentences ('He visited Vancouver, Halifax and the city of Québec'). ${ }^{6}$

The descriptive translations 5 and 6 may also not fit into certain sentence structures. In addition, like Translation 4, they are rather wordy and therefore not suited for repetition in a text which refers frequently to this city. Finally, 5 and 6 add information not contained in the French original: both add the information that this city is the capital, and 6 adds information about Quebec's constitutional status as a province of Canada, which in some politically sensitive texts might be incompatible with the intention of the French writer.

\subsection{Radio-Canada}

The next proper name to be considered is the name of a federal institution, Canada's state broadcaster, which is called "the CBC" (Canadian Broadcasting Corporation) in English and "(Société) Radio-Canada” in French. The Corporation is organized into separate English and French radio and television networks. Here is a sentence with five possible translations of "Radio-Canada":

Her new documentary will be airing on

\begin{tabular}{|l|l|l|l|}
\hline & otherness evoked? & hard to read? & $\begin{array}{l}\text { misunderstanding } \\
\text { likely? }\end{array}$ \\
\hline 1. Radio-Canada & possibly & no & yes \\
\hline 2. Radio-Canada & probably & no & yes \\
\hline $\begin{array}{l}\text { 3. the French network of the } \\
\text { CBC }\end{array}$ & no & no, unless repeated & no \\
\hline $\begin{array}{l}\text { 4. Radio-Canada [the French } \\
\text { network of the CBC] }\end{array}$ & yes & $\begin{array}{l}\text { yes, if many } \\
\text { brackets in text }\end{array}$ & no \\
\hline 5. the CBC & no & no & yes \\
\hline
\end{tabular}

The French name of the Corporation, in Translations 1 and 2, will not be recognized by many English-Canadians outside Quebec. Indeed some may confuse it with the Corporation's international broadcasting service, Radio Canada International, though they may wonder why there is a hyphen (a very common feature of French but not English proper names, so that removal of the hyphen, as in 'Shawinigan South,' creates a more English feel). Some readers of Translations 1 and 2 may also mistakenly believe that the documentary will be airing on radio rather than on television, for in everyday English the word 'radio' does not include television broadcasting. These translations are not hard to read because the form will be familiar from expressions like "Radio Free Europe." However, since the form is familiar, the cultural otherness of the entity in question may not be apparent. The probability of evoking 
otherness will be greater with Translation 2, especially if French words elsewhere in the text are italicized.

Translation 3 simply describes the French nature of the entity; it does not embody cultural otherness (there are no accent marks or obviously unEnglish words). Unlike Translations 1 and 2, it will not give rise to misunderstanding. While it is not hard to read, it is lengthy and therefore would not bear repetition (though this could be remedied by simply writing "French CBC").

Translation 4 makes it clear, through the presence of the English in brackets, that 'Radio-Canada' is intended to be French. However, the bracketed expression will add to the reading burden, especially if there are a great many such explanatory additions in the text. There is no likelihood of misunderstanding unless context fails to make it clear that television rather than radio is meant.

Translation 5 will almost certainly be misunderstood: our Vancouver reader will assume that the documentary will be broadcast on the Corporation's English network. The sense of cultural otherness is completely absent.

Note that, unlike the case with Quebec City, there is no translation available which simultaneously prevents misunderstanding, is easy to read, and evokes otherness, though Translation 4 would qualify in this regard provided the text is not full of bracketed explanations.

\subsection{Acadie}

Here is a sentence containing a reference to the French-speaking region of the province of New Brunswick, in eastern Canada:

Ronald Tremblay roule sa bosse dans la francophonie canadienne depuis 1976. Ses principaux ports d'attache ont été l'Acadie et l'Alberta où il demeure depuis 1985.

Ronald Tremblay has been all around French-speaking Canada since 1976, mostly staying in .................. and Alberta (where he has been living since 1985).

\begin{tabular}{|l|l|l|l|}
\hline & otherness evoked? & hard to read? & $\begin{array}{l}\text { misunderstanding } \\
\text { likely? }\end{array}$ \\
\hline 1. Acadia & possibly & no & possibly \\
\hline $\begin{array}{l}\text { 2. French New Brunswick or the } \\
\text { French-speaking part of New } \\
\text { Brunswick }\end{array}$ & no & $\begin{array}{l}\text { no, unless } \\
\text { repeated }\end{array}$ & no \\
\hline 3. New Brunswick & no & no & yes \\
\hline
\end{tabular}

Translation 1 anglicizes the French name of the region and therefore cultural otherness may or may not be evoked in the reader. The result is not hard to read, but the name, even with the anglicization, may not be recognized by English Canadians who have never lived in the eastern provinces of Canada. Still, there may be some readers in Vancouver who recognize the word, and for them Translation 1 will simultaneously avoid misunderstanding, be easy to read and evoke otherness.

Translation 2 has the same characteristics as Translation 3 of Radio-Canada. Translation 3 has the same characteristics as Translation 5 of Radio-Canada except that, rather than creating misunderstanding, it eliminates part of the meaning, by naming the province as a whole rather than just its French-speaking area. 


\subsection{Commission québécoise des libérations conditionnelles}

While some Quebec institutions have official English names, most do not. Let's look at possible translations of one such institution, the parole board. Quebec and two other provinces of Canada have their own parole boards, institutionally separate from the National Parole Board operated by the central government (the Quebec board is not a branch of the national board).

You must apply to

\begin{tabular}{|l|l|l|l|}
\hline & otherness evoked? & hard to read? & $\begin{array}{l}\text { misunderstanding } \\
\text { likely? }\end{array}$ \\
\hline $\begin{array}{l}\text { 1. the Commission québécoise des } \\
\text { libérations conditionnelles }\end{array}$ & yes & yes & $\begin{array}{l}\text { yes (possibly no } \\
\text { understanding at all) }\end{array}$ \\
\hline $\begin{array}{l}\text { 2. the Commission québécoise des } \\
\text { libérations conditionnelles }\end{array}$ & yes & $\begin{array}{l}\text { yes, but less } \\
\text { so }\end{array}$ & $\begin{array}{l}\text { yes (possibly no } \\
\text { understanding at all) }\end{array}$ \\
\hline $\begin{array}{l}\text { 3. the CQLC [Quebec parole board] } \\
\text { 4. the Parole Board }\end{array}$ & yes & nomewhat & no \\
\hline $\begin{array}{l}\text { 5. the Quebec parole board; or } \\
\text { Quebec's parole board }\end{array}$ & no & no & possibly \\
\hline 6. the provincial parole board & no & no & no \\
\hline
\end{tabular}

While Translation 1 certainly evokes otherness, it will be very hard for a unilingual Anglophone to read, and misunderstanding is very likely; indeed, depending on what other information is available from context, the reader may be completely baffled. Unlike the case with place names, institutions tend to have names whose parts need to be understood in order for the message to get across to target-language readers. Translation 2 is somewhat less hard to read because the italics visually signal the special status of these words in the text.

Translation 3 evokes otherness to a degree (assuming the reader notices that CQLC is not an acronym for the English words 'Quebec parole board'). This translation is somewhat hard to read because the acronym is not transparent. However, because of the bracketed expression, there will not be any misunderstanding. If the institution is referred to again later in the text as 'the CQLC', with no explanatory bracket, readers may have forgotten the explanation, and if they cannot then easily find the earlier occurrence, they may not understand the sentence. Still, of the six translations, Translation 3 comes closest to simultaneously avoiding misunderstanding, being easy to read, and evoking otherness. It is not as successful in this regard, however, as Translation 1 of 'Acadie,' and it is far less successful than Translation 2 of 'Québec.'

Translation 4 eliminates the sense of otherness. While it is easy to read, there is a risk of complete misunderstanding: the reader may think the reference is to the National Parole Board. This risk is eliminated by Translation 5 but here, cultural otherness is simply described rather than being embodied in the words of the translation. Translation 6 adds a reference to the constitutional status of Quebec, which may be contrary to the source writer's intent.

Let's now look at institution names in some longer sentences. 


\begin{tabular}{|l|l|}
\hline $\begin{array}{l}\text { 1. One of our partners was Destination } \\
\text { Centre-Ville, which is the Société d'initiatives } \\
\text { et de développement des artères commerciales } \\
\text { for downtown Montreal. }\end{array}$ & $\begin{array}{l}\text { At the Bureau de la mise en cuvre du } \\
\text { partenariat public-privé of the Ministère des } \\
\text { transports, our interest is mainly in electronic } \\
\text { payment services. }\end{array}$ \\
\hline $\begin{array}{l}\text { 2. One of our partners was Destination } \\
\text { Centre-Ville, the Société d'initiatives et de } \\
\text { développement des artères commerciales } \\
\text { [commercial development association for } \\
\text { downtown Montreal]. }\end{array}$ & $\begin{array}{l}\text { At the Quebec transportation ministry's } \\
\text { Bureau de la mise en ceuvre du partenariat } \\
\text { public-privé, which is responsible for creating } \\
\text { transportation infrastructure in partnership } \\
\text { with the private sector, our interest is mainly } \\
\text { in electronic payment services. }\end{array}$ \\
\hline $\begin{array}{l}\text { 3. One of our partners was the commercial } \\
\text { development association for downtown } \\
\text { Montreal. }\end{array}$ & $\begin{array}{l}\text { At the office for public-private partnerships } \\
\text { of the Quebec Department of transport, our } \\
\text { interest is mainly in electronic payment } \\
\text { services. }\end{array}$ \\
\hline
\end{tabular}

In the two sentences in Box 1, the French institution names are untranslated and unitalicized. These sentences are almost unreadable, and their meaning is unlikely to come across to our unilingual Anglophone from Vancouver.

In Box 2, the names are italicized and are followed by either an informal translation in brackets or an explanation. The meaning comes across, but the reading process will be awkward. In Box 3, the French names have been eliminated. These sentences are highly readable and understandable, but despite the mentions of Quebec and Montreal, cultural otherness will not be evoked. Note how, on the right side of Boxes 2 and 3, the treatment of the Quebec Government's Ministère des transports is somewhat different from the treatment of the other institution name. In Box 2, a translated description is used; in Box 3, an English institution name is used, modelled on the English name of the federal government's Department of Transport, except that 'transport' is lower-cased to indicate that the English is not official in Quebec. (Such lower-casing is common practice among Canadian translators working into English, though one may wonder whether readers understand its intended significance).

Sometimes translators make their decision about the treatment of Quebec institution names on the basis of a style guide or client instructions. Here the situation is rather varied. The Quebec Government insists on leaving the names of government institutions in French, without translation or explanation added ${ }^{7}$. The federal government's style guide The Canadian Style contains no instructions on translating Quebec institution names. The Canadian Press Style Book says that "Stories peppered with French break the flow and make reading difficult" and it recommends anglicization (1999: 202-3), which means that one should write 'University of Montreal', not 'Université de Montréal', and 'Quebec College of Veterinarians' rather than 'Order of Veterinary Doctors of Quebec' for 'Ordre des médecins vétérinaires du Québec.' As this latter example shows, use of capital letters on all major words in a name (contrary to the practice in French) contributes to creating familiarity for English readers; the capitalization is however somewhat misleading since in fact this institution does not have an official English name. 


\subsection{Canada, canadien}

With this place name, the issue is not whether French words will be retained, but rather what happens, in terms of reader reaction, when the corresponding English words (Canada, Canadian) are used in translations from French. As we will see, what happens is that in some cases, the English words will be used in ways which are not normal in English Canada, and as a result translators may seek other solutions.

In French, the word 'canadien' can have one of several different meanings: (i) pan-Canadian, that is, Canadian in the English sense of the word, referring to the country as a whole; (ii) federal, that is, pertaining to the central government; (iii) English-Canadian, that is, Canada minus Quebec. In English-speaking Canada, 'Canadian' is used in sense (ii) only in specialized (mostly legal) contexts; and it is used in sense (iii) only by that segment of the political left which adheres to the view that Canada is not a single nation but consists of two nations (Quebec and [English] Canada $)^{8}$.

With regard to sense (ii), it is commonplace in French writing to refer to federal government departments as 'canadien': 'ministère de la justice canadien.' However English-Canadian readers (unlike Anglophone audiences outside Canada) will be baffled if this is translated 'Canadian department of justice,' because that will be taken to mean the Canadian as opposed to, say, the U.S. or Italian department of justice. The normal way English-Canadians distinguish a department of the central government from a department of a provincial government is to use the adjective 'federal': 'federal Department of Justice' as opposed to "Quebec Department of Justice." A translation that uses the word 'federal' might of course be contrary to the intent of whoever wrote 'ministère de la justice canadien,' since for some readers 'federal' will evoke a contrast with 'provincial,' thus creating a reference to Quebec's constitutional status as a province (not a 'nation').

Here is an example of sense (iii) of 'canadien/Canada':

La mise sur pied au printemps 2002 du Consortium - Ouranos sur la climatologie régionale et l'adaptation aux changements climatiques vise justement à combler les lacunes identifiées en la matière. Il résulte d'un partenariat institutionnel regroupant plusieurs ministères québécois, Hydro-Québec, des universités québécoises et des partenaires canadiens. [In spring 2002, the Ouranos consortium on regional climatology and adaptation to climate change was established to make up for these deficiencies. It brought together in an institutional partnership several Quebec government departments, Hydro-Quebec, some Quebec universities and......']

Translating the last three words of the second sentence as 'some Canadian partners' will either baffle or annoy most Anglophone readers, since it seems to imply that Hydro-Quebec and Quebec universities are not Canadian institutions. To avoid such an implication, and the consequent reader reaction, the translator might resort to a wording such as 'partners elsewhere in Canada.'

Similarly the expression 'au Québec et au Canada' might be translated 'in Quebec and in the rest of Canada' if the aim is to avoid annoying Anglophone readers. There are two exceptions: first, contexts where it is clear that the expression means in Quebec in particular and in Canada in general (i.e., Canada including Quebec rather than Canada minus Quebec), ' for example in a statistical text that might be entitled 'a study of educational achievement in Quebec and Canada'; and second, legal contexts where 
an expression such as 'agreement between Quebec and Canada' is commonly used to mean 'between the Quebec government and the federal government.'

Since the difficulty in translating 'Canada / canadien' is related to the question of whether Quebec is seen as a 'nation,' let's briefly look at translations of the French word 'national' in institution names. Consider four possible translations of the Quebec institution known as the 'Bibliothèque nationale du Québec':

1. the BNQ (Quebec's provincial library)

2. Quebec's provincial library

3. the National Library of Quebec

4. the National Library

Translations 1 and 2 replace the notion of the library as an institution of the Quebec 'nation' with a reference to the constitutional status of Quebec as a province of Canada. Translation 3 may annoy some readers for the reason already given, though other readers may take it as paralleling the name of Quebec's legislature, which has long been referred to in English Canada as the 'National Assembly.' Translation 4 may, depending on context, risk confusion with the National Library of Canada, a federal institution. ${ }^{9,10}$

This concludes my consideration of the reader-reaction factor in determining the selection of a particular translation of a place name or institution name. An interesting question is the extent to which conscious consideration of reader reaction plays a role in translation. Other factors, to be considered in the remainder of the article, may be the deciding ones. Of course, even when anticipated reader reaction plays a negligible role, the real reader will still experience the sometimes subtle effects of a particular translation that have been discussed above. Empirical study of such actual effects would be of great interest: because of the frequency with which proper names occur, their translation has a far more pervasive sociopolitical effect on readers than the translations of more overtly ideological expressions (e.g., will 'souverainté' be translated 'sovereignty' or 'separation'?).

\section{Role of clients, authors, professional organizations and employers}

In this section, I want to briefly consider how the translator may be affected by parties to the translation process other than the imagined future reader.

First, clients. A translator might justify a translation by saying 'the client said to do it that way.' Here the translator adopts a servant role vis-à-vis the paymaster, and claims to have translated in the specified way regardless of any reader-related factors. What role client wishes actually play in determining how certain expressions are translated has never been studied. Under what circumstances do translators ignore these wishes? To what extent do clients have editors who override the translator's decision if it doesn't conform to the client's wishes? These are questions which merit study.

Second, authors. A translator may consider the reaction of Francophone sourcetext authors to a particular English translation, at least with 'outbound' translations - those commissioned by the authors themselves or by someone else on the sourcelanguage side. With 'inbound' translations - those commissioned on the targetlanguage side - the author will often not know that the text is being translated. 
Third, the organized translation profession: does it have anything to say about the kinds of decisions we are considering? No, to judge by the Code of Ethics of the Canadian Translators and Interpreters Council (http: //www.synapse.net/ctic/e_ ethics.htm). It would probably be hard for such an organization to prepare a position that most translators would agree to, because there are two conflicting views on such matters: that translators should be guided by others (follow style guides, follow client instructions), and that translators should use their own judgment, possibly overriding any prescriptions.

Finally, what about the role of those who hire translators (whether as salaried employees or contractors)? If the employer of a translator is a culture ministry or book publisher, then it might be expected to take an interest in decisions about partly cultural/ideological matters such as proper name translation. Until 1993, the Canadian federal government's Translation Bureau was part of the culture ministry (known as the Department of the Secretary of State), and cultural considerations did perhaps have some influence on the translation into English of French proper names. For example, by the late 1970s the practice of anglicizing Quebec place names when referring to them in English was being discouraged (the city of Trois-Rivières used to be referred to as Three Rivers; the region of Quebec adjacent to Ontario along the Ottawa River, now called 'the Outaouais,' was known as the Ottawa Valley, the name used on the Ontario side of the border). Use of the French name rather than an anglicized version was codified in the Government's style guide, prepared by the Translation Bureau and published in $1985 .^{11}$

Since 1995, the Translation Bureau has been operating within the government services ministry (Public Works and Government Services Canada), and on a costrecovery basis; that is, it has to sell its translations to government departments and thereby cover salary and other costs. Under these circumstances, economic pressures (notably maximizing revenue per unit time) have perhaps come to be more important than cultural ones. In the next section, I suggest that economic pressures from employers manifest themselves in the form of various workplace procedures that may play a determining role in proper name translation, perhaps overriding all the factors we have considered so far.

\section{Workplace procedures as factors in the translation of proper names}

If a translator were asked to explain why he had translated 'Bibliothèque nationale du Québec' as 'Quebec provincial library' he might give a reader-reaction explanation: "I wanted to maximize readability" or "I wanted to avoid annoying readers with the notion of Quebec having a 'national' library." Alternatively the translator might invoke instructions from clients, authors, employers or style guides, as discussed in the previous section.

A rather different kind of answer, which I now want to consider at some length, is: "we always do it that way." This answer is somewhat ambiguous; at a more conscious level, it may mean that the translation service where the translator works prizes consistency; or it may mean that a style guide adopted by the translation service specifies a certain way of translating. At a more unconscious level, this answer may manifest the workings of political ideology (denial of Quebec as a nation). However all these interpretations of the answer have one thing in common: they all concern habits. 
As everyone in the profession knows, adopting a habitual way of translating a particular expression serves to speed up the translation process. Speed is of course a key economic consideration: the faster one translates, the more money one makes (or the more money one's employer makes). Every time one stops to make a judgment, rather than use a habitual translation for an expression, valuable time is used up. Any workplace practice which allows the translator to avoid making a conscious decision about how to translate an expression will be favoured when speed is of the essence. Thus the answer to the question 'why was this expression translated this way' may have nothing to do with the specific passage at hand, or the anticipated reactions of the reader; the answer may simply be: habit.

Now, the demand for speed can affect translation not only by encouraging the use of habitual translations but also by encouraging practices which so to speak 'preselect' a given translation (though not necessarily the same translation every time). Specifically, I am thinking of practices related to re-using old translations or re-using existing documentation in the target language.

Consider the following sentence fragment from a text sent by Quebec's transportation ministry to the federal Department of Transport, commenting on federal policy (a translation was requested for Anglophones in the federal Department):

...passe par l'architecture canadienne des systèmes de transport intelligents...

An original English document on intelligent transportation systems (ITS), found on a federal Department of Transport Web site, contained the following phrase:

...depends on a national ITS architecture...

The translator (the present writer) cut-and-pasted the entire English sentence containing this phrase, which proved to be incorporable, with a small amount of editing, into the translation. If no such document had been found, some other translation of 'canadienne' might have resulted, perhaps 'Canada-wide,' or 'pan-Canadian,' or even 'federal.' 'National' has no special merit as a translation, but it was present in an existing English sentence that lent itself to cutting-and-pasting, and therefore it was used. In cut-and-paste translation, one does not contrast the merits of several different translations; one simply asks whether the candidate for pasting is adequate. A cut-andpaste procedure sometimes proves to be faster than composing a fresh translation.

Another effect of the demand for increased speed is a reduction of the time allowed for quality control. Less quality control means less enforcing of rules. Thus a certain employer may well have proclaimed certain rules about the translation of place names and institution names, but the smaller the amount of time devoted to enforcing these rules, the less effect they will have on the outcome. As a result, while each individual translator may use a habitual translation, it may not be the one desired by the employer, and furthermore it may not be the one habitually used by that translator's colleagues. It will be a case of "this is the way I always do it" rather than "this is the way we always do it." Habit will still operate, but the result will be diversity rather than uniformity in a large body of translations.

The two factors just discussed (reduction in quality control time and use of cutand-paste to compose translations) can of course combine to create great diversity in the way a particular proper name is translated: the different documents from which translators perform cut-and-paste operations may well have differing treatments of 
a given proper name, and if translations are not subject to thorough quality control, then such inconsistencies will not be eliminated.

A final effect of speed is of course carelessness. A translator in a hurry may simply not notice that there are any issues surrounding the translation of 'architecture canadienne' in the above example. He will quickly write 'Canadian architecture' and rush on to the next bit of the text, not noticing that 'Canadian' suggests a contrast with other countries, a contrast not intended by the French writer of the source text.

In this article, I have suggested several factors that may influence the translation of proper names, but I have not mentioned the translator's own views, conscious and unconscious. For example, to what extent does the translator believe that readability should outweigh any consideration related to evoking cultural otherness? To what degree does the translator follow rules even when they are not being enforced? What are the translator's own views about the relationship between Quebec and the rest of Canada? These beliefs will surely have some effect on the outcome. That said, however, I want to conclude by suggesting that the role of workplace procedures as determining factors in translation has not received as much attention as it deserves.

There has been a tendency in Translation Studies to focus on conscious decisionmaking by the translator or on the political/cultural/ideological goals of commissioners and translators. The fact that translation is an economic activity, one which people engage in not just to get messages across but to make a living, or a profit, has not yet fully registered in our field. Translations are created in workplaces, and the translation of frequent textual features such as proper names will I think prove to be an area where workplace procedures play an important role.

\section{NOTES}

1. At the 'most conscious' level, the translator would formulate to himself the reason for translating an expression in a certain way while translating it. At a lower level, a macrodecision would be made, before translation begins, about the treatment of proper names; certain choices would then flow from this when a name is encountered in the text. At a still lower level, the translator's individual approach to translation, or personal ideological stance, would dictate a certain choice without much conscious thought.

2. Non-Canadian readers should realize that few residents of Vancouver will come into routine contact with French, apart from signs on federal government buildings. French is in fact not much used outside Quebec and parts of two adjacent provinces. In addition, few Vancouverites can read French. On the 1996 census, only 7.4\% of those in the Vancouver area reported knowledge of both English and French; almost all of this would represent knowledge of French as a second language since only $1.4 \%$ of the population had French as their first language. Canada is not a bilingual society. Rather it has federal institutional bilingualism (the central government operates across the country in both languages). The individual provinces, within their constitutional areas of jurisdiction, have their own language regimes. One province (New Brunswick) is officially bilingual and one province (Quebec) is officially unilingual. The rest have no official language; in practice they operate in English, though a few (not including British Columbia, on the Pacific coast of Canada, where Vancouver is located) have legislation under which certain services are provided in French to the linguistic minority.

3. Another possibility, ignored here for simplicity's sake, is that the reader will take the text to be original English, but with non-English features present for reasons of local colour, snob appeal or political correctness.

4. Unfortunately there is no way to search in Alta Vista for cases where Québec occurs in an English text without the word City following, yet is still a reference to the city rather than the province.

5. The first edition of The Canadian Style, published in 1985, made the contrast in a single sentence: "Quebec (the province) is to be written in English without the accent, whereas Québec (the city) retains the accent” (1985: 227). 
6. Writing 'He visited Vancouver, Halifax and Québec' may be somewhat baffling: English-Canadians are not used to referring to the city in this way, and therefore they will have to make a conscious deduction that the city rather than the province is intended. Oral announcements on Air Canada flights sometimes use Québec without City, but the context makes the intention clear since flights are always bound for specific cities.

7. Many English translations on Quebec Government Web sites, and on some sites run by the Quebec regional offices of federal government departments, border on the unreadable because of nontranslation of institution names, combined with an absence of italicization to visually separate French from English. Reader comprehension will often be limited to Anglo-Quebeckers, who are used to seeing French institution names, and a very high percentage of whom are bilingual. Here's an example (see qc.ec.gc.ca/atmos/smog/infogen_e.html ): "INFO-SMOG is a joint program of the Ministère de la Santé et des Services sociaux du Québec in collaboration with the Directions de la santé publique, the City of Montréal, the Quebec ministry of the Environment (MEQ) and Environment Canada (EC). The warnings issued by the INFO-SMOG program are enriched by the participation of the ministère des Transports du Québec..” It might be of interest to compare these government information sites directed at Anglo-Quebeckers with pages directed at international audiences such as tourists, investors or prospective immigrants.

8. Simplifying somewhat for non-Canadian readers, the view of Canada as a binational entity is held by the overwhelming majority of French-speaking Quebeckers, whether they are politically 'federalists' or 'sovereignists.' They see themselves as 'Québécois' who also happen to be citizens of a federation called Canada. The great majority of English-Canadians have a very different view: that Canada is a single nation divided into ten provinces, in one of which most people happen to speak French. They see themselves as 'Canadians' first, and secondarily as residents of one of the provinces.

9. Many texts refer to both a federal institution and the parallel Quebec institution, which may have exactly the same name: the Ministère des transports (department of transport], the Commission de la Capitale Nationale [national capital commission]. The translator's choice of wording is often explainable in terms of avoiding reader uncertainty as to which institution (federal or provincial) is being referred to at any given point in the text.

10. Not all uses of 'national' in French have ideological implications. For example, in the Quebec Government's terminology bank, the Grand dictionnaire terminologique, the English equivalent of 'route nationale' is given as 'main road.'

11. This was part of a broader trend in Canadian society that also manifested itself in the replacement of English or French place names by Aboriginal place names. Thus in 1987, the town of Frobisher Bay was officially renamed Iqaluit; it is now the capital of the Territory of Nunavut, where the majority speak Inuktitut. It may be noted that the town described at the outset of this article as having the French name 'Shawinigan-Sud' actually has a mixed name: the second word is French, but the first is Abenaki (one of the Algonquian languages).

\section{REFERENCES}

Department of the Secretary of State (1985): The Canadian Style: A Guide to Writing and Editing, Toronto and London, Dundurn Press.

Editors' Association of Canada (2000): Editing Canadian English, 2nd edition, Toronto, Macfarlane Walter \& Ross.

Public Works and Government Services Canada (1997): The Canadian Style: A Guide to Writing and Editing, revised edition, Toronto and Oxford, Dundurn Press.

Tasko, P. (ed.) (1999): The Canadian Press Stylebook, 11th edition, Toronto, The Canadian Press.

Trahan, V. (2001): City of Montréal Style Guide: a handbook for translators, writers and editors, Montreal, Service du greffe, Ville de Montréal. 